Holmes's Comet (Igo6f).-In No. 412I of the Astronomische Nachrichten Prof. Max Wolf states that he has measured the position of Holmes's comet on the plate secured on August 28. He gives the exact position, for 1906.0, at the time of discovery, and this shows that corrections of $+6 \cdot 79 \mathrm{~s}$. and $+2 \delta^{\prime \prime} \cdot 2$ are necessary to Dr. Zwiers's ephemeris. As the comet is extremely faint, mag. $=15.5$, a continuation of the cphemeris is not given here, but will be found in No. 4085 of the Astronomische Nachrichten.

Observations of Solar Piienomena, igo6.-The results of the observations of sun-spots, faculæ, and prominences made during the first semester of the present year at the Catania Observatory are published by Prof. Mascari in No. 8, vol. xxxv., of the Memorie della Societa degli Spettroscopisti Italiani.

The mean daily frequency of spots was higher during the second than during the first quarter, the respective numbers being 5.68 and $4.5^{\circ}$; the faculæ behaved similarly. For prominences the reverse was the case, there being a mean daily frequency of 4.38 prominences during the first quarter and 3.47 during the second. Discussing the results in relation to the time of the solar maximum, Prof. Mascari places the epoch of maximum spots at 1905.2 , and that of facula and prominences in the last quarter of 1905 or the first quarter of 1906 .

OBSERVATIONS OF JUPITER.-The observations of Jupiter made by $\mathrm{Mr}$. Denning during the last opposition showed that the rotation period of the Great Red Spot and its Hollow, in the south equatorial belt, between March 24 and May 4, was $9 \mathrm{~h}$. $55 \mathrm{~m}$. $40 \cdot 6 \mathrm{~s}$., a period practically conformable with that of system ii. of the ephemerides. On observing the phenomena on August 9, however, he found that they were far in advance of their predicted places, an observation confirmed by the Rev. T. E. R. Phillips. From this it appears that the rotation period between May 4 and August 8 was only 9h. $55 \mathrm{~m}$. $33.8 \mathrm{~s}$. Mr. Denning supposes that the conjunction of the dark material, forming the south tropical disturbance, with the Red Spot, in June last, may have caused the marked acceleration of the latter, as it has done on several former cccasions. The present increase of velocity is, however, much greater than any previously observed, and these features appear to have been observable for seventy-five years (the Observatory, No. 374).

In the September number of the Bulletin de la Société astronomique de France M. Flammarion directs attention to a remarkably sudden change in the visibility of the north equatorial band on Jupiter. This band has been diminishing since the end of 1903, and an observation made by M. Benoit, at Juvisy, on April 10, I906, showed that it was almost completely invisible. After its conjunction with the sun, Jupiter was observed again on July i 7 by M. Quenisset, who was astonished to find that the north equatorial band was completely reformed, being even broader, and at some points darker, than the south equatorial band. A drawing, made by M. Quenisset on July 23, is reproduced with the article.

Tife Kodaikanal Observatory.-An interesting popular account of India's solar physics observatory, situated at Kodaikanal, on the Palani Hills, appears in the July number of the Madras Christian College Magazine. Mr. Monteith Macphail, the writer of the account, lately visited the observatory, and was evidently impressed with its situation and its work. The altitude of the observatory is about 7700 feet, in an atmosphere of exceptional transparency, and amid beautiful surroundings.

Although located in Madras, the institution was founded, and is supported, by the Government of India, thus having a national and not merely a provincial status. Its chief raison d'être is the continuous study of the sun, with the ultimate idea of elucidating still further the indicated relationships between solar and terrestrial atmospheric phenomena. To a country like India, the value of possessing the fullest possible knowledge of these relationships cannot be overestimated, and that is the reason why the Government of India has seen fit to found and to support this observatory and its equipment in the most favourable situation at its command. Sun-spots, their spectra, and prominences on the solar limb, are observed visually, and spectroheliograms of the solar disc and limb are taken on every day on which the atmospheric conditions are suitable. Magnetical and seismological records are also taken.

\section{CHEMISTRY AT THE BRITISH ASSOCIATION.}

$\mathrm{I} \mathrm{T}$ was somewhat noticeable that the trend of the proceedings in Section B this year was in the direction of applied chemistry ; general problems on the theoretical side of the science came under discussion in Section A; if this indicate either that this section is becoming alive to the importance of chemistry to physics or a rapprochement of the two sections, it is a good sign, but it is not satisfactory if it mean the neglect of broad considerations by the chemist.

Reports were presented by Mr. S. S. Pickles, on the chemistry of rubber; on that of gums, by $\mathrm{Mr}$. $\mathrm{H} . \mathrm{H}$. Robinson; and on the hydrolysis of sugars, by Mr. R. J. Caldwell. These gave rise to more or less interesting discussions and were a valuable feature of the meeting. Discussion also centred round a paper by Dr. T. A. Henry, on the production of hydrogen cyanide in plants. The joint discussion with the physiologists on diet was of great interest, although it was mainly developed in physiological and sociological directions.

The proceedings opened on the Thursday, August 2, with an important paper by Messrs. S. Leetham and Wm. Cramp, who have been engaged in perfecting an apparatus for the production of an active mixture of gases which may be used for bleaching and sterilising purposes, particularly in bleaching flour. The apparatus consists of an alternator, transformer, ozoniser and spark box, the two latter being in series on the high-tension side of the transformer; on passing a current of air through the ozoniser and then through the spark box a gaseous mixture is produced, containing minute amounts of ozone and oxides of nitrogen, which has a very remarkable bleaching and sterilising action on flour; the process is already one of considerable commercial value. The bleaching action appears to be an oxidation effect.

The authors have studied in great detail the behaviour of the different types of electric discharge and the influence of such factors as the number and distance apart of the discharge points, shape of the points, the air velocity and the frequency. The conclusion arrived at is that ozonisation is not a mere induction effect. In commenting on the paper, Prof. Armstrong dwelt on the importance of manufacturers taking interest in science, and referred to the work as an illustration of the advantages of such cooperation.

Following a short paper by Prof. van Romburgh, of Utrecht, on the $1: 3: 5$-hexatrien, reports were read of the committees on dynamic isomerism, on hydro-aromatic substances and on aromatic nitro-amines. The rest of the morning was devoted to inorganic chemistry, papers being contributed by Mr. A. Vernon Harcourt, on the effect upon the concentration of a solution of the presence of an excess of undissolved salt; by Mr. G. Beilby, on the crystallisation of gold in the solid state; and by Prof. H. A. Miers and Miss F. Isaac, on the temperature at which water freezes in sealed tubes; this is found to be very considerably below that at which solidification takes place in open vessels.

The greater part of Friday, August 3, was devoted to a discussion on the production of hydrogen cyanide in plants. introduced by Prof. Dunstan, who pointed out that in the case of both Lotus arabicus and Sorghum vulgare the cyanide was formed only during the early stages of growth, and that it was missing in the mature plant. The fullygrown Lotus vetch is much used as a fodder plant in the Nile valley, but manv fatal cases of poisoning have been caused through its use in the immature state. Hydrogen cvanide has also been detected in Java beans, of which there are several varieties; the maximum amount is found in the dark beans, and it is only safe to use the light bean. In the flax plant, which also affords hydrogen cyanide, the maximum amount is produced at an inter-

No. I925, vot. 74] 
mediate stage when the plant is from 4 inches to 5 inches high.

Dr. Henry followed with an account of the glucosides containing the hydrogen cyanide, which have been grouped together as cyanogenetic glucosides. They are allied to amygdalin, the active principle in bitter almonds, which is therefore the oldest known representative of the group. The list at present comprises, besides amygdalin, sambunigrin, prulaurasin and a glucoside, prepared artificially from amygdalin by Fischer, known as mandelnitrileglucoside, all of which are resolved by acids into glucose, benzaldehyde and hydrogen cyanide; further, dhurrin, phaseolunatin, lotusin and gynocardin.

The plants containing these glucosides also contain enzymes, which resolve them--when the plant is macerated with water-into hydrogen cyanide, glucose and a third constituent. The question was raised as to the role of the hydrogen cyanide, whether it acted protectively or whether it played a part in the production of proteid from nitrates. Dr. Greshoff, of Harlem, dealt with the question from the botanical side, and put forward a list of all the species of plants known to yield hydrogen cyanide, which will be of great value to future workers.

A paper on the utilisation of atmospheric nitrogen by plants, read by Mr. Thomas Jamieson, described what the author regarded as special organs in plants adapted for the direct absorption and assimilation of nitrogen from the air. His conclusions were most severely criticised by Prof. Potter from the botanical side, and by Mr. A. D. Hall and others.

The report on caoutchouc, presented by Mr. S. S. Pickles, contained a general survey of the chemistry of this remarkable product.

Prof. Karl Harries, of Kiel, in a communication read by Dr. Crossley, dealt with the products obtained by submitting caoutchouc to the action of ozone, and then distilling the ozonide with steam, viz. lævulinic aldehyde, lævulinic acid and hydrogen peroxide. Harries concludes that caoutchouc is a polymer of a i : 5-dimethylcyclo-octadien. Prof. W. A. Tilden described his observations on the behaviour of isoprene, prepared from oil of turpentine; when kept it gradually polymerises, being converted into a substance having many of the properties of caoutchouc. He also contributed a paper on the constituents of Dyera Costulata.

Mr. H. H. Robinson followed with a brief account of the chemistry of gums, dwelling especially on gums from India and the colonies which afford acetic acid when exposed to the action of moist air. He suggested that by partially hydrolysing the inferior Indian gums they might be made of greater industrial value. In the subsequent discussion, Mr. S. H. Davies stated that constitution had so far been found to have little bearing on the technical value of gums, viscosity being the quality chiefly required.

In his report, Mr. R. J. Caldwell collected and critically discussed the literature bearing on the hydrolysis of sugars, a subject of considerable interest at the present moment on account of its bearing on the theory of ionic dissociation and the nature of solution. Nearly 150 papers have been published on the subject, so that it is very difficult for a new worker in the field to acquaint himself with the literature. Mr. Caldwell has made a brief abstract of the essential points in each paper, and classified them in historical order under a number of appropriate subheadings. He sums up the evidence as to the nature of the change, and points out the unsatisfactory character of the argument based on the dissociation hypothesis that it is brought about by the hydrogen ions of the acid. He is inclined to believe that the facts are to be explained by an association hypothesis.

A large part of the morning of Tuesday, August 7, was devoted to a joint discussion with Section I (physiology) on the factors which determine minimal diet values. This was opened by Dr. F. G. Hopkins, F.R.S.; Prof. Dunstan and Prof. Armstrong spoke on the chemical side. It was generally agreed that the subject was of supreme importance, and one that should be attacked conjointly by chemists and physiologists. Dr. Hopkins dealt chiefly with the standards of minimal diets. put forward by Atwater, Voit and Chittenden respectively. These are incorporated in the following table:-

No. I925 vOL. 74]

\begin{tabular}{lcccccc} 
& \multicolumn{4}{c}{$\begin{array}{c}\text { Energy value in } \\
\text { calories per diem }\end{array}$} & \multicolumn{2}{c}{ Protein per diem } \\
Investigator & \multicolumn{4}{c}{ diem } \\
Atwater & $\ldots$ & $\ldots$ & 3500 & $\ldots$ & $\ldots$ & 125 \\
Voit $\ldots$ & $\ldots$ & $\ldots$ & 3050 & $\ldots$ & $\ldots$ & 1 I 8 \\
Chittenden & $\ldots$ & $\ldots$ & 2600 & $\ldots$ & $\ldots$ & 55
\end{tabular}

The methods and results of these workers were considered and criticised in detail. While Atwater's standard was thought to be too high, it was generally agreed that Chittenden's values were too low. Voit's standard was accepted as the most probable.

Mr. Seebohm Rowntree's well-known experiments carried out in York were referred to, and it was pointed out that in studying actual dietaries of poor families averages were used in compiling statistics, a method which is open to criticism, as the bread-winner-owing to the self-denial of the woman-as a rule, gets far more than his share, so that the diet of the average working man is actually in most cases far richer in protein and has a greater energy value than is imagined.

Attention was directed by Dr. Hopkins-and this point was particularly emphasised by Prof. Armstrong-that it was not justifiable to consider merely the gross amount of protein, but that the nature of the protein had also to be taken into account. Thus, for example, wheat is probably not the best form of protein, its main constituent, glutaminic acid, being, so far as our present knowledge goes, of relatively little value as a tissue former compared with other amino-acids. Maize protein is perhaps of even lower value, whereas rice and nats, among the cereals, appear to be the especially valuable sources of protein. Prof. Armstrong particularly referred to the need of making detailed study of foodstuffs, our present method of referring to the nitrogen content generally multiplied by a factor as protein giving no true guide as to the relative value of foods, inasmuch as protein is a highly complex material, made of ever-varying units, the nutritive value of which taken singly varies within wide limits.

The rest of the morning was devoted to agricultural chemistry, Messrs. A. D. Hall and C. T. Gimingham contributing a paper on the action of ammonium salts upon clay and kindred substances, following which Dr. E. J. Russell read a communication by Dr. F. V. Darbishire and himself on oxidation in soils and its relation to productiveness. These authors have devised an apparatus for measuring the rate of absorption of oxygen; the power of absorbing this gas possessed by all soils appears to be due mainly, though not entirely, to the activity of microorganisms. The rate of oxidation does not entirely depend on the amount of organic matter present in the soil; moisture is essential, and as it increases so also does the rate of oxidation. The rate is also increased by the addition of calcium carbonate or of sugar. For a series of similar soils, of which the cropping power is known, it is found that the most productive has the highest rate of oxidation, and that the others follow in the same order for both properties. The parallelism holds also for soils which have been artificially treated; it is essential, however, that the soil conditions should be aërobic. The authors suggest that the rate of oxidation affords a measure of the bacterial activity, which is closely connected with productiveness.

The last paper read was by $\mathrm{Mr}$. W. Popplewell Bloxam, on a new method of determining indigotin. After pointing out the need of a method of controlling the still very crude processes in vogue for extracting indigo, and the importance of determining the daily yield of indigotin obtained in an ordinary factory from known weights of green plant, the existing methods of analysis were discussed and the uncertainty of the results they afford alluded to. In the author's method, the indigotin is sulphonated by treatment with fuming sulphuric acid (containing 20 per cent. sulphur trioxide); the solution is then diluted, and the potassium salt of indigotin tetrasulphonate precipitated by means of potassium acetate. Finally, the amount of indigotin in the salt is estimated by titration with potassium permanganate or titanium chloride. The author concludes that the present process of manufacture is a wasteful one, the highest efficiency attained not reaching $5^{\circ}$ per cent., whilst on the average only 25 per cent. of the indigotin in the leaves is extracted. 